\title{
The relationships of Amphipogon, Elytrophorus and Cyperochloa (Poaceae) as suggested by rbcL sequence data
}

\author{
Nigel P. Barker
}

\begin{abstract}
Nigel P. Barker ${ }^{1}$ (National Herbarium of New South Wales, Royal Botanic Gardens, Sydney, Mrs Macquaries Road, Sydney, NSW, Australia 2000. 'Present address: Dept. Botany, Rhodes University, PO Box 94, Grahamstown, 6140, South Africa; email: barker@rhobot.ru.ac.za) 1997. The relationships of Amphipogon, Elytrophorus and Cyperochloa (Poaceae) as suggested by rbcL sequence data. Telopea 7(3): 205-213. The phylogenetic affinities of Amphipogon, Elytrophorus and Cyperochloa are elucidated using DNA sequence data from the chloroplast $r b c \mathrm{~L}$ gene. All three genera were previously considered to belong to the subfamily Arundinoideae tribe Arundineae. However, cladistic analysis of $r b c \mathrm{~L}$ sequence data obtained in this study suggests that Cyperochloa has no affinities with the Arundinoideae, and that Amphipogon and Elytrophorus have affinities with the Arundineae sensu stricto, but not the Danthonieae.
\end{abstract}

\section{Introduction}

The classical subfamilial and tribal classification of the grass family has been under much scrutiny recently. Several studies have utilised DNA sequence data to resolve relationships between and within the subfamilies (Barker et al. 1995 \& submitted, Clark et al. 1995, Cummings et al. 1994, Davis \& Soreng 1993, Doyle et al. 1992, Duvall \& Morton 1996, Hsiao et al. in press, Liang \& Hilu 1996, Mathews et al. 1996, Nadot et al. 1994). These studies have modified our understanding of the relationships of the major grass lineages, and (with suitable sample sizes) can provide an indication of the composition of these lineages.

Molecular studies on the Bambusoideae (Clark et al. 1995) and Arundinoideae (Barker et al. 1995 \& submitted) have indicated that these subfamilies are polyphyletic, comprising several unrelated lineages. With respect to the Arundinoideae, this merely confirms what has been long suspected, as Renvoize (1981), Campbell (1985), Clayton \& Renvoize (1986), Conert (1987), Ellis (1987), Kellogg \& Campbell (1987) \& Watson (1990) have all considered this group to be polyphyletic.

Molecular systematic studies are, however, often restricted to taxa that are readily available. Taxa that are ephemeral, narrowly endemic or found in remote areas that require long distance collecting trips are seldom included. These taxa are nonetheless important in such studies, as they may represent unsampled or under-represented clades or biogeographic outliers, and are thus potentially valuable in clarifying phylogenetic and biogeographic relationships. Material of three such genera, Elytrophorus, Amphipogon and Cyperochloa, was recently collected in Australia. Coincidentally, the taxonomic position and phylogenetic affinities of these three genera are uncertain, as existing morphological and anatomical data provides unclear or conflicting indications of higher level affinities. The use of molecular (DNA sequence-based) techniques to resolve the subfamilial and possibly tribal affinities of these three genera is thus appropriate. 
The choice of which particular gene to use in elucidating these relationships is important, and there are several data sets now available for the grasses. These include $r b c \mathrm{~L}$ (Barker et al. 1995, Duvall \& Morton 1996, Seberg \& Linde-Laursen 1996), $n d h \mathrm{~F}$ (Clark et al. 1995), rpoC2 (Barker et al. submitted, Cummings et al. 1994), rps4 (Nadot et al. 1994) and nuclear ribosomal RNA internal transcribed spacer regions (ITS; Hsiao et al. in press). Sequence data from $r b c \mathrm{~L}$ are appropriate for showing the affinities of these three genera, as $r b c \mathrm{~L}$ sequences are available for a wide range of arundinoid taxa as well as other grass lineages, and they are not subject to potential alignment problems associated with the more variable sequences such as rpoC2 (Barker et al. submitted), rps4 (Nadot et al. 1994) and ITS (Hsiao et al. in press).

\section{Materials and methods}

DNA was extracted from dried leaf material of Elytrophorus and Amphipogon by means of the hot CTAB method (Doyle \& Doyle 1987). An aliquot of DNA of Cyperochloa was provided by C. Hsiao. Voucher and other details of these samples are given in Table 1.

The $r b c \mathrm{~L}$ gene from Amphipogon was amplified and sequenced according to the method published by Barker et al. (1995). The rbcL gene of Elytrophorus and Cyperochloa was amplified using primer 'A1' (designed by P. Gadek \& S. Gilmore, University of New South Wales) and the reverse primer designed by Zurawski (Z-1375R). The amplification products were purified by means of the Promega Wizard DNA Clean-up system. The ABI PRISM dye terminator cycle sequencing kit was used to generate DNA for sequencing. Sequencing was carried out by SUPAMAC (Sydney University and Prince Alfred Macromolecular Analysis Centre) using an ABI PRISM 377 autosequencer. The two flanking primers and four internal primers were used in a total of six sequencing reactions for each template, producing a complete sequence in both directions. The primer sequences used are listed in Table 2.

Sequences were edited using Sequencher version 3.0 (Gene Codes Corporation, Inc. 1995). Once edited, the sequences were imported into DAPSA (DNA And Protein Sequence Analysis; E.H. Harley, Dept. Chemical Pathology, University of Cape Town), where they were added to the data set used in an earlier analysis (Barker et al. 1995) as well as four additional sequences of taxa of the subfamily Bambusoideae obtained from GenBank. It must be noted that not all the published grass $r b c \mathrm{~L}$ sequences were used in the analysis presented here. In some instances, some of the published sequences could not be found in GenBank, and in other instances there were several species sequenced from a single genus. In the latter instance, a single taxon was selected at random to represent that particular genus. Other than four species of Bambusoideae mentioned above, all the additional sequences in GenBank were from taxa in the subfamily Pooideae.

DAPSA was used to align and manipulate these sequences and to produce data in a format suitable for phylogenetic analyses. An initial phylogenetic analysis was carried out using HENNIG86 (Farris 1988). PAUP version 3.1.1 (Swofford 1993) was used for subsequent analyses. A search to find islands of most parsimonious trees (Maddison 1991) was carried out using 100 random addition replicates, keeping a maximum of 10 trees at each replicate. The trees found from this search were then swapped to completion in a HEURISTIC search using the TBR option. Bootstrap support values (Felsenstein 1985) were estimated from one hundred bootstrap replications, and Bremer support values (Bremer 1988) for trees up to three steps longer were obtained using PAUP. As the monotypic Joinvilleaceae is the closest extant relative of the Poaceae (Campbell \& Kellogg 1987; Doyle et al. 1992; Linder \& Rudall 1993; Kellogg \& Linder 1995), Joinvillea is used as the outgroup. 
Table 1. Voucher details of the specimens sequenced in this study

\begin{tabular}{|c|c|c|c|}
\hline Taxon & Collector & Locality & GenBank No. \\
\hline Amphipogon strictus R.Br. & H.P. Linder 5634 & Kings Tableland, NSW & U88403 \\
\hline $\begin{array}{l}\text { Cyperochloa hirsuta Lazarides } \\
\& \text { L. Watson }\end{array}$ & T.D. Macfarlane 22586 & Stirling Range, WA & U88404 \\
\hline Elytrophorus globularis Hack. & S.W.L. Jacobs 7964 & Yelarbon, S. Qld & U88405 \\
\hline
\end{tabular}

Table 2. The sequences of the primers used for amplification and sequencing

Note that the numbers associated with the names of the primers do not indicate exact nucleotide positions along the gene.

$\begin{array}{ll}\text { Primer } & \text { Sequence } \mathbf{( 5}^{\prime}-\mathbf{3}^{\prime} \text { ) } \\ \text { A1 } & \text { GGGATTTATGTCACCACAAACAGA (PCR and sequencing) } \\ 380 \mathrm{~F} & \text { GCTTATTCAAAAACTTCCAAGGCCCGC (sequencing) } \\ 860 \mathrm{~F} & \text { ATTCACCGCGCAATGCATGC (sequencing) } \\ 670 \mathrm{R} & \text { TGTGCTTTATAAATTGCTTCGGC (sequencing) } \\ 930 \mathrm{R} & \text { GCTAGTACACGAAAATGCATACC (sequencing) } \\ \text { Z1375R } & \text { AATTTGATCTCCTTCCATATTTCGCA (PCR and sequencing) }\end{array}$

\section{Results and discussion}

A preliminary analysis of the complete data set (comprising representatives of all the genera in GenBank) produced 424 trees. The strict consensus of these trees was well resolved in all areas except the subfamily Pooideae, which was reduced to a polychotomy (results not shown). For the analysis discussed here, the sequences of the pooid taxa Elymus, Leymus, Bromus and Eremium were excluded to break the pooid polytomy and reduce the number of trees and thus search time. The final data set comprised 163 phylogenetically informative characters. The random entry analysis and subsequent search found 12 equally parsimonious trees (length 516 steps, c.i. $=0.40$, r.i. $=0.69$ ), all of which were also found by the HENNIG86 analysis. The strict consensus tree is shown in Fig. 1. Bootstrap \& Bremer support values are shown on this Fig.

The relationships of the major clades (subfamilies and tribes) in both the preliminary analysis and the analysis presented here are unchanged from those presented by Barker et al. (1995). However, bootstrap support is weak for some of these lineages, such as the (Aristideae, Danthonieae, Chloridoideae) clade (54\% in Fig 1). The relationships of Amphipogon, Elytrophorus and Cyperochloa are shown to be diverse, and each genus is discussed separately below.

Cyperochloa is a monotypic Australian genus, first described by Lazarides \& Watson (1986). It was placed in the Arundinoideae on the basis of a variety of anatomical and morphological characters, including a ligule which is a fringe of hairs, laterally flattened spikelets which disarticulate above the glume, fleshy, ciliate lodicules and 3-5-nerved lemmas. Lazarides \& Watson (1986) conducted a phenetic computerised comparison that placed this genus in the tribe Danthonieae, where it was considered 


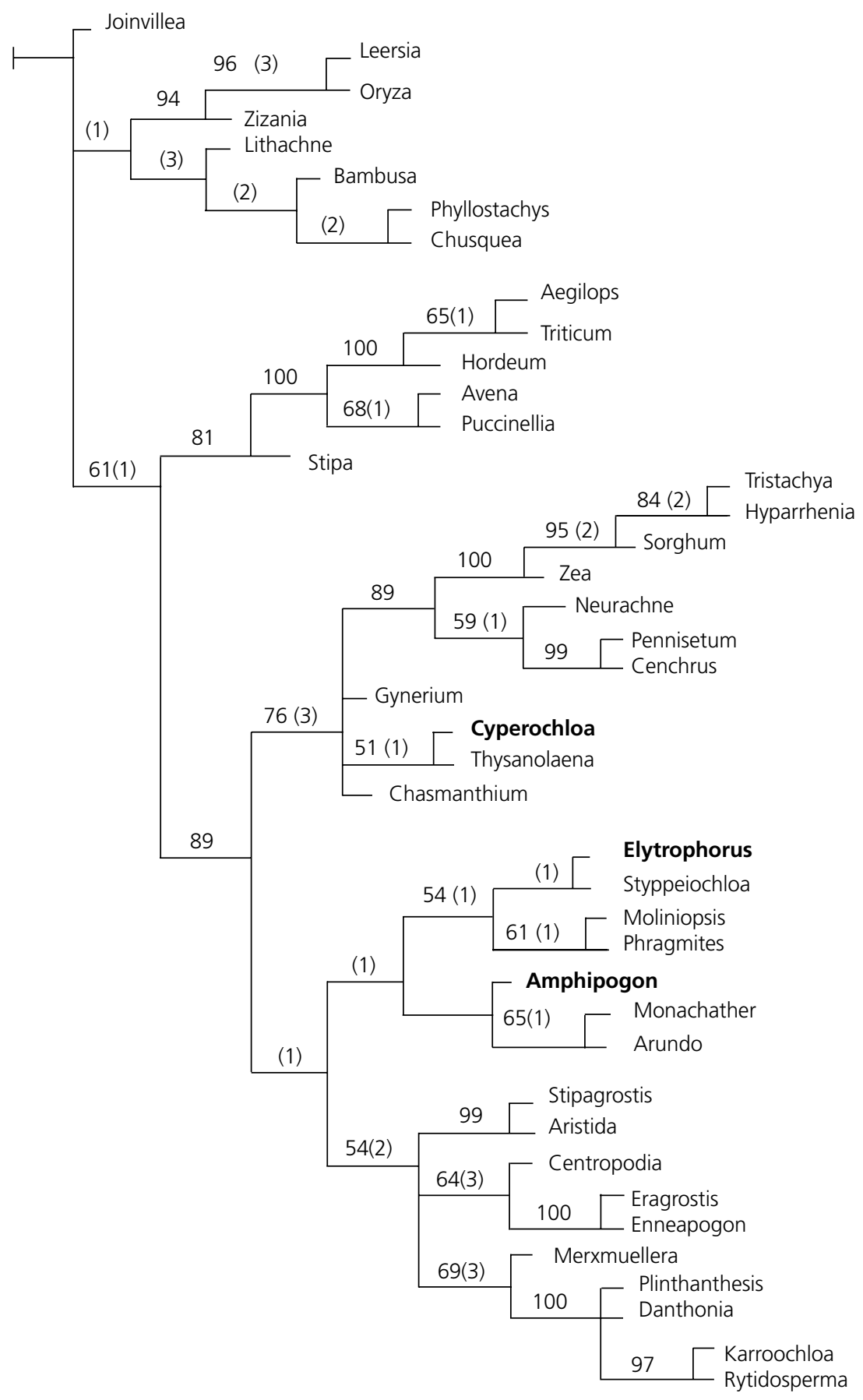

Fig. 1. The strict consensus tree of 12 equally parsimonious trees found using the search options described in the methods section. Tree length $=516$ steps, c.i. $=0.40$, r.i. $=0.69$. Bootstrap support values from 100 replicates are shown on nodes receiving more than $50 \%$ support. Values in parentheses indicate Bremer support values. Where no Bremer support values are given then the branch is retained in trees more than three steps longer. 
to occupy an isolated position in the vicinity of Plagiochloa (= Tribolium), followed by the Australasian Danthonia, Erythanthera (= Rytidosperma sensu Linder \& Verboom 1996), Schismus, Plinthanthesis, Monachather and Spartochloa. Watson \& Dallwitz (1992) place it in its own tribe, the Cyperochloeae, in the Arundinoideae.

The rbcL data shows that Cyperochloa is not an arundinoid grass, as it is placed as sister to Thysanolaena in a larger clade comprising members of the subfamily Panicoideae and Centothecoideae. Although bootstrap and Bremer support for the sister relationship to Thysanolaena is weak, support for the inclusion of these two genera in the enlarged panicoid clade is strong $(76 \%)$. Thysanolaena, placed in the monotypic tribe Thysanolaeneae in the subfamily Arundinoideae by Clayton \& Renvoize (1986), has been shown to be related to the Centothecoideae in other molecular studies (Barker et al. 1995 \& submitted, Clark et al. 1995). The affinities of Cyperochloa and Thysanolaena (and the reedy Gynerium) with the Centothecoideae and Panicoideae needs to be further investigated using both molecular and morphological characters.

Elytrophorus and Amphipogon are placed in the tribe Arundineae as defined by Watson \& Dallwitz (1992). This tribe is represented here by seven genera. As yet, no morphological characters have been found to support this clade. Nonetheless, it is interesting to note that, with the exception of Anisopogon (and the unsampled Dichaetaria), the composition of this clade of seven taxa is almost identical to the list of arundinoid taxa with atypical ligules provided by Clayton \& Renvoize (1986, p. 165). A detailed comparative investigation into the ontogeny and structure of the ligule might thus be rewarding.

Amphipogon is an Australian genus comprising seven species (Vickery 1950). Watson \& Dallwitz (1992) place this genus, along with Diplopogon, in its own tribe, the Amphipogoneae in the Arundinoideae. They further note that the spikelet form (especially the lemma) and microhairs (chloridoid or Enneapogon type) are reminiscent of Enneapogon, thus suggesting chloridoid affinities for this genus. Renvoize (1981, 1986) considered Amphipogon to have an anomalous leaf blade anatomy, in that it possessed papillate long cells and lacked microhairs, the latter character suggesting a position in the Pooideae. A recent survey of the genus by Linder (pers. comm.) failed to find any microhairs, supporting Renvoize's observations. Despite this apparent confusion, Clayton \& Renvoize (1986) placed Amphipogon in the tribe Arundineae (Arundinoideae), a position also supported by the results of a phenetic analysis carried out by Hilu \& Wright (1982), which placed Amphipogon in the Arundinoideae basal to Arundo, Phragmites and Cortaderia. In contrast, support for a pooid placing for Amphipogon was found by Kellogg \& Campbell (1987) in their cladistic analysis of mainly morphological characters.

The results from the analysis presented here confirm that Amphipogon is associated with the Arundineae (sensu Watson \& Dallwitz 1992) and is related to Arundo and Phragmites. Amphipogon is basal to the (Arundo, Monachather) clade, an association that is well supported (95\% bootstrap support; Fig. 1).

Elytrophorus is a widespread genus ranging from southern and tropical Africa through to China and the Indian subcontinent to Australia. Despite this widespread distribution, it inhabits remote areas in both Africa and Australia, and is thus seldom collected. It is water-loving, being found at the edges of seasonal pans, ponds and rice fields, and is considered to be a true hydrophyte, possessing aerenchyma tissue (Schweickerdt 1942). Schweickerdt recognises four species, while Chippindall (1955), Clayton (1970) \& Barker (in Gibbs Russell et al. 1994) recognise only two.

Opinions on the affinities of Elytrophorus have been varied. Chippindall (1955), Bor (1960) and Clifford \& Watson (1977) interpreted it to be a chloridoid grass. Prat (1960) could not place it in any group with confidence, while Decker (1964) considered it to 
have similarities with the Danthonieae. Jacques-Félix (1962) put it in its own tribe, the Elytrophoreae, in the Arundinoideae. Renvoize (1981, 1986) and Clayton \& Renvoize (1986) place it in the Arundinoideae, tribe Arundineae, while Watson \& Dallwitz (1992) place it in the Danthonieae. Schweickerdt (1942), however, considered the unusual dimorphic spikelets and membranous, unfringed to fringed ligule of Elytrophorus to be at odds with a position in the Danthonieae. Dimorphic spikelets are found elsewhere in the grasses, and have probably evolved several times within the family. The fruit is laterally compressed and is unlike that of any other African arundinoid genus (Barker 1994). It must be noted, however, that laterally compressed fruit is also a generic character in Andropogoneae and Chloridoideae, and is also found in some species of Eragrostis. There is also some confusion regarding the degree of attachment of the pericarp; Schweickerdt (1942) notes that the fruit 'show the remains of the pericarp', implying that it is separable (the fruit thus being an achene), while Clayton \& Renvoize (1986) consider the pericarp to be free, but do not specify the fruit as an achene. Scanning electron micrographs do not resolve this issue with any certainty (Barker 1994). A light microscopy study of the embryology of E. spicatus suggests that the pericarp is represented by its outer epidermis only, which is adnate to the inner layer of the inner integument (Satyamurty 1985). Unfortunately, Satyamurty (1985) makes no mention of the presence (or absence) of haustorial synergid cells, a character that is considered to be a synapomorphy for the Danthonieae (Philipson 1977, Philipson \& Connor 1984, Verboom et al. 1994). Evidence from leaf anatomical studies suggest that Elytrophorus has affinities with the $\mathrm{C}_{3}$ panicoid taxa such as Sacciolepis and Acroceras, rather than the $C_{3}$ Danthonieae (Ellis 1986).

Elytrophorus is shown in this study to be sister to Styppeiochloa, a genus considered by Linder et al. (1997) to be part of the crinipoid clade, a group that includes the African genera Alloeochaete, Crinipes, Dichaetaria, Leptagrostis, Nematopoa, Piptophyllum and the Indian and Sri Lankan genera Dichaetaria and Zenkeria. Although the relationship between Elytrophorus and Styppeiochloa is not well supported by bootstrap or Bremer support measures, the relationship between Elytrophorus and the crinipoid clade needs to be re-examined in light of this association. In particular, the homology of the bracts and bract-like structures associated with the dimorphic spikelets of Elytrophorus needs to be assessed.

\section{Conclusion}

The expanded $r b c \mathrm{~L}$ sequence dataset analysed here retains the relationships between the various major lineages found in a previous study (Barker et al. 1995). With the exception of Amphipogon, which is well supported as the basal taxon to the (Arundo, Monachather) clade, the $r b c \mathrm{~L}$ sequence data do not provide strong support for the immediate affinities of the three taxa sampled here. Cyperochloa is shown to be excluded from the Arundinoideae, and is placed sister to Thysanolaena in a panicoid centothecoid clade that is well supported. The data suggest that both Elytrophorus and Amphipogon are members of the tribe Arundineae sensu Watson \& Dallwitz (1992).

As these taxa may be isolated, possibly basal, members of these clades further evidence and support for their affinities may only become clearer and stronger as additional samples are added to the data set. It is therefore important that continued efforts be made to obtain material of these unusual taxa, and the $r b c \mathrm{~L}$ and other data sets expanded. Finally, the caveat stated in an earlier study (Barker et al. 1995) and elsewhere (Doyle 1992) needs to be re-iterated: $r b c \mathrm{~L}$ data retrieve a plastid phylogeny (as opposed to an organismal phylogeny) and relationships obtained from this source of data need to be tested against phylogenies obtained from morphological or nuclear DNA data. 


\section{Acknowledgments}

Financial support in the form of the Royal Botanic Gardens, Sydney, Research Fellowship is gratefully acknowledged. I would like to thank Dr Surrey Jacobs (Royal Botanic Gardens, Sydney) and A/Prof. H. Peter Linder (Dept. Botany, University of Cape Town) and two anonymous referees for suggestions and comments on an earlier draft of this paper. The collectors of material of Amphipogon and Elytrophorus, listed in Table 1, and Cathy Hsiao (USDA - ARS Forage and Range Research Laboratory, Utah State University, Logan, Utah) who provided an aliquot of her DNA extract of Cyperochloa are gratefully acknowledged. Dr C. Morton (Dept. Botany, University of Reading) is thanked for providing computer time and access to her copy of PAUP. Ms Jessica Vamathevan of SUPAMAC (Sydney University and Prince Alfred Macromolecular Analysis Centre) provided technical assistance in the sequencing carried out in Sydney, Australia.

\section{References}

Barker, N.P. (1994) External fruit morphology of southern African Arundineae (Arundinoideae: Poaceae). Bothalia 14: 55-66.

Barker, N.P., Linder, H.P. \& Harley, E.H. (submitted) Sequences of the grass-specific insert in the chloroplast rpoC2 gene elucidates generic relationships of the Arundinoideae (Poaceae). Systematic Botany.

Barker, N.P., Linder, H.P. \& Harley, E.H. (1995) Polyphyly of Arundinoideae (Poaceae): evidence from $r b c$ L sequence data. Systematic Botany 20: 423-435.

Bor, N.L. (1960) Grasses of Burma, Ceylon, India and Pakistan. (Pergamon Press: London).

Bremer, K. (1988) The limits of amino acid sequence data in angiosperm phylogenetic reconstruction. Evolution 42: 795-803

Campbell, C.S. (1985) The subfamilies and tribes of Gramineae (Poaceae) in the southeastern United States. Journal of the Arnold Arboretum 66: 123-199.

Campbell, C.S. \& Kellogg, E.A. (1987) Sister group relationships of the Poaceae. Pp. 217-224 in Soderstrom, T.R., Hilu, K.W., Campbell, C.S., \& Barkworth, M.E. (eds), Grass Systematics and Evolution. (Smithsonian Institution Press: Washington DC).

Chippindall, L.K.A. (1955) A guide to the identification of grasses in southern Africa. Part 1 of D. Meredith, The Grasses and Pastures of South Africa. (Central News Agency: Cape Town).

Clark, L.G., Zhang, W. \& Wendel, J.F. (1995) A phylogeny of the grass family (Poaceae) based on $n d h \mathrm{~F}$ sequence data. Systematic Botany 20: 436-460.

Clayton, W.D. (1970) Gramineae (Part 1). In Milne-Readhead, E.W.B.H. \& Polhill, R.M. (eds), Flora of Tropical East Africa. (Crown agents: London).

Clayton, W.D. \& Renvoize, S.A. (1986) Genera Graminum. (Her Majesty's Stationery Office: London).

Clifford, H.T. \& Watson, L. (1977) Identifying Grasses: data, methods and illustrations. (University of Queensland Press: St Lucia).

Conert, H.J. (1987) Current concepts in the systematics of the Arundinoideae. Pp. 239-250 in Soderstrom, T.R., Hilu, K.W., Campbell, C.S., \& Barkworth, M.E. (eds), Grass Systematics and Evolution. (Smithsonian Institution Press: Washington DC).

Cummings, M.P., King, L.M. \& Kellogg, E.A. (1994) Slipped strand mispairing in a plastid gene: rpoC2 in grasses (Poaceae). Molecular Biology and Evolution 11: 1-8.

Davis, J.I. \& Soreng, R.J. (1993) Phylogenetic structure in the grass family (Poaceae) as inferred form chloroplast DNA restriction site variation. American Journal of Botany 80: 1444-1454.

Decker, H.F. (1964) An anatomic-systematic study of the classical tribe Festuceae (Gramineae). American Journal of Botany 51: 453-463.

Doyle, J.J., Davis, J.I., Soreng, R.J., Garvin, D. \& Anderson, M.J. (1992) Chloroplast DNA inversions and the origin of the grass family (Poaceae). Proceedings of the National Academy of Sciences, USA 89: 7722-7726.

Doyle, J.J. (1992) Gene trees and species trees: molecular systematics as one-character taxonomy. Systematic Botany 17: 144-163.

Doyle, J.J. \& Doyle, J.L. (1987) A rapid DNA isolation procedure for small quantities of fresh leaf tissue. Phytochemical Bulletin 19: 11-15. 
Duvall, M. R. \& Morton, B. R. (1996) Molecular phylogenetics of Poaceae: an expanded analysis of rbcL sequence data. Molecular Phylogenetics and Evolution 5: 352-358.

Ellis, R.P. (1986) Leaf anatomy of the South African Danthonieae (Poaceae). XV. The genus Elytrophorus. Bothalia 16: 243-249.

Ellis, R.P. (1987) A review of comparative leaf blade anatomy in the systematics of the Poaceae: the past twenty-five years. Pp. 3-10 in Soderstrom, T.R., Hilu, K.W., Campbell, C.S., \& Barkworth, M.E. (eds), Grass Systematics and Evolution. (Smithsonian Institution Press: Washington DC).

Farris, J.S. (1988) HENNIG86 version 1.5.

Felsenstein, J. (1985) Confidence limits on phylogenies: an approach using the bootstrap. Evolution 39: 783-791.

Gene Codes Corporation, Inc. (1995) Sequencher, version 3.0. (Gene Codes Corporation, Inc.: Ann Arbor, Michigan).

Gibbs Russell, G.E., Watson, L., Koekemoer, M., Smook, L., Barker, N.P., Anderson, H.M. \& Dallwitz, M.J. (1990) Grasses of southern Africa. Memoirs of the Botanical Survey of South Africa No. 58. (National Botanical Institute: Pretoria).

Hilu, K.W. \& Wright, K. (1982). Systematics of Gramineae: a cluster analysis study. Taxon 31: 9-36.

Hsiao, C. , Jacobs, S.W.L., Barker, N.P. \& Chatterton, N.J. (in press) A molecular phylogeny of the subfamily Arundinoideae (Poaceae) based on sequences of rDNA. Australian Systematic Botany.

Jacques-Félix, H. (1962) Les graminées d'Afrique Tropicale. 1. Généralités, classification, description des genres. (Institut de Recherches Agronomiques Tropicales et des Cultures Vivières: Paris).

Kellogg, E.A. \& Campbell, C.S. (1987) Phylogenetic analysis of the Gramineae. Pp. 310-322 in Soderstrom, T.R., Hilu, K.W., Campbell, C.S., \& Barkworth, M.E. (eds), Grass Systematics and Evolution. (Smithsonian Institution: Washington, DC).

Kellogg, E.A. \& Linder, H.P. (1995) Phylogeny of Poales. Pp. 511-542 in Rudall, P.J., Cribb, P.J., Cutler, D.F. \& Humphries, C.J. (eds), Monocotyledons: systematics and evolution. (Royal Botanic Gardens: Kew).

Lazarides, M. \& Watson, L. (1986) Cyperochloa, a new genus in the Arundinoideae Dumortier (Poaceae). Brunonia 9: 215-221.

Liang, H. \& Hilu, K.W. (1996) Application of the matK gene sequences to grass systematics. Canadian Journal of Botany 74: 125-134.

Linder, H.P. \& Rudall, P.J. (1993) The megagametophyte in Anarthria (Anarthriaceae, Poales) and its implications for the phylogeny of the Poales. American Journal of Botany 80: 1455-1464.

Linder, H.P. \& Verboom, G.A. (1996) Generic limits in the Rytidosperma (Danthonieae, Poaceae) complex. Telopea 6: 597-627.

Linder, H.P., Verboom, G.A. \& Barker, N.P. (1997) Phylogeny and evolution in the Crinipes group of grasses (Arundinoideae: Poaceae). Kew Bulletin 52: 91-110.

Maddison, D.R. (1991) The discovery and importance of multiple islands of most-parsimonious trees. Systematic Zoology 40: 315-328.

Mathews, S. \& Sharrock, R.A. (1996). The phytochrome gene family in grasses (Poaceae) - a phylogeny and evidence that grasses have a subset of the loci found in dicot angiosperms. Molecular Biology and Evolution 13: 1141-1150.

Nadot, S., Bajon, R. \& Lejeune, B. (1994) The chloroplast gene rps4 as a tool for the study of Poaceae phylogeny. Plant Systematics and Evolution 191: 27-38.

Prat, H. (1960) Vers une classification naturelle des graminées. Bulletin, Société botanique de France 107: 32-79.

Philipson, M.N. (1977) Haustorial synergids in Cortaderia (Gramineae). New Zealand Journal of Botany 15: 777-778.

Philipson, M.N. \& Connor, H.E. (1984) Haustorial synergids in danthonioid grasses. Botanical Gazette 145: 78-82.

Renvoize, S.A. (1981) The subfamily Arundinoideae and its position in relation to a general classification of the Gramineae. Kew Bulletin 36: 85-102.

Renvoize, S.A. (1986) A survey of leaf-blade anatomy in grasses VIII. Arundinoideae. Kew Bulletin 41: 323-338.

Satyamurty, T.V.Ch. (1985) Embryology of Elytrophorus spicata. Phytomorpology 35: 11-15.

Schweickerdt, H.G. (1942) A taxonomic and anatomical study of Elytrophorus Beauv. Annals of the Natal Museum 10:191-214.

Seberg, O. \& Linde-Laursen, I. (1996) Eremium, a new genus in the Triticeae (Poaceae) from Argentina. Systematic Botany 21: 3-15. 
Swofford D.L. (1993) PAUP: Phylogenetic Analysis Using Parsimony, version 3.1.1. (Smithsonian Institution: Washington DC).

Verboom, G.A., Linder, H.P. \& Barker, N.P. (1994) Haustorial synergids: An important character in the systematics of danthonioid grasses (Arundinoideae: Poaceae). American Journal of Botany 81: $1601-1610$

Vickery, J. (1950) The species of Amphipogon R.Br. (Gramineae). Contributions from the New South Wales National Herbarium 1: 281-295.

Watson, L. (1990) The grass family, Poaceae. Pp. 1-31 in Chapman, G.P. (ed.), Reproductive Versatility in the Grasses. (Cambridge University Press: Cambridge)

Watson, L. \& Dallwitz, M.J. (1992) The Grass Genera of the World. (C.A.B. International: Cambridge).

Manuscript received 24 February 1997

Manuscript accepted 15 August 1997 
